Agro Ekonomi Vol. 27/No. 2, Desember 2016

\title{
PERMINTAAN KEDELAI PADA INDUSTRI RUMAH TANGGA TAHU DI KABUPATEN SLEMAN
}

\author{
Demand for Soybean on Tofu Industry in Sleman Regency
}

\author{
${ }^{1}$ Farid Styawan, ${ }^{2}$ Dwidjono Hadi Darwanto, ${ }^{2}$ Lestari Rahayu Waluyati \\ ${ }^{1}$ Bank BRI \\ ${ }^{2}$ Departemen Sosial Ekonomi Pertanian, Fakultas Pertanian, Universitas Gadjah Mada \\ Jl. Flora, Bulaksumur, Yogyakarta 55281 \\ faridstyawan95@gmail.com
}

Diterima tanggal : 12 September 2016 ; Disetujui tanggal : 15 Oktober 2016

\begin{abstract}
The needs of domestic consumption of soybean tends increasing every year, one of them for tofu industry inputs. This study aims to determine: 1) the factors that affect the demand for soybean on tofu industry in Sleman Regency, 2) the value-added generated from tofu industry in Sleman Regency, 3) the factors that affect tofu industry profits in Sleman Regency. The method used in this research is descriptive analysis method. This research was conducted in Seyegan districts and Gamping districts in 2016, and taken proportionally 65 people tofu industry as respondents. Factors that affect demand for soybean on tofu industry and the factors that affect tofu profitability were calculated using linear regression analysis, while the value-added on tofu industry calculated using the value-added method of Hayami. The results showed that demand for soybean is affected by soybean prices, labor costs, the price of firewood, and the ownership status of the milling machine. Then, the value-added of fried tofu is Rp 5.602,4/kg of soybean, the value-added of white tofu is Rp 5.175,2/kg of soybean, and the value-added of yellow tofu is Rp $3.999,6 / \mathrm{kg}$ of soybean. The results also showed that the profits of tofu industry in Sleman affected by labor costs, the price of soybeans, production capacity, business experience, and the price of coagulant.
\end{abstract}

Keywords: demand for soybean, profit, tofu, value-added.

\section{INTISARI}

Kebutuhan konsumsi masyarakat terhadap kedelai cenderung mengalami peningkatan setiap tahunnya, salah satunya untuk kebutuhan industri tahu. Penelitian ini bertujuan untuk mengetahui: 1) faktor-faktor yang mempengaruhi permintaan kedelai pada industri tahu di Kabupaten Sleman, 2) besarnya nilai tambah yang dihasilkan dari industri tahu di Kabupaten Sleman, 3) faktor-faktor yang mempengaruhi keuntungan pengrajin tahu di Kabupaten Sleman. Metode yang digunakan dalam penelitian ini adalah metode deskriptif analitis. Penelitian ini dilaksanakan di kecamatan Seyegan dan kecamatan Gamping pada tahun 2016, dan sebanyak 65 orang pengrajin tahu diambil secara proporsional sebagai responden. Faktor-faktor yang mempengaruhi permintaan kedelai pada industri tahu dan faktor yang mempengaruhi keuntungan pengrajin tahu dihitung dengan menggunakan analisis regresi linear berganda, sedangkan nilai tambah pada industri tahu dihitung dengan menggunakan rumus nilai tambah metode Hayami. Hasil penelitian menunjukkan bahwa permintaan kedelai dipengaruhi oleh harga kedelai, upah tenaga kerja, harga kayu bakar, dan status kepemilikan mesin giling. Kemudian, nilai tambah tahu goreng sebesar Rp 5.602,4/kg kedelai, nilai 
tambah tahu putih sebesar Rp 5.175,2/kg kedelai, dan nilai tambah tahu kuning sebesar Rp $3.999,6 / \mathrm{kg}$ kedelai. Hasil penelitian juga menunjukkan bahwa keuntungan industri tahu di Kabupaten Sleman dipengaruhi oleh upah tenaga kerja, harga kedelai, kapasitas produksi, pengalaman usaha, dan harga koagulan.

Kata kunci: keuntungan, nilai tambah, permintaan kedelai, tahu

\section{PENDAHULUAN}

Kedelai merupakan komoditas pokok yang banyak mengandung protein dan menyehatkan bagi tubuh, selain itu tanaman ini juga termasuk murah dan dapat terjangkau oleh masyarakat. Seiring dengan meningkatnya jumlah dan kesadaran penduduk tentang pentingnya mengkonsumsi makanan bergizi, mengakibatkan tingkat konsumsi dan permintaan terhadap makanan olahan kedelai mengalami peningkatan. Peningkatan ini disebabkan karena kebutuhan konsumsi masyarakat yang cenderung meningkat, baik di konsumsi langsung dalam bentuk susu kedelai maupun dalam bentuk minyak kedelai (McFarlane and O’Connor, 2014). Di masa mendatang, permintaan terhadap kedelai ini diprediksi akan terus mengalami peningkatan yang cukup signifikan dan berbanding lurus dengan pertambahan jumlah penduduk di Indonesia (Damardjati et al., 2005). Di sisi lain, peningkatan kebutuhan konsumsi kedelai oleh masyarakat Indonesia ini tidak dapat diimbangi peningkatan jumlah produksi kedelai dalam negeri (Tanoyo, 2014).

Berdasarkan data dari Direktorat Jenderal Industri Kecil dan Menengah Kementerian Perindustrian tahun 2011,
Industri Kecil dan Menengah (IKM) olahan kedelai ini berjumlah \pm 92.400 unit usaha yang didominasi untuk IKM Tempe dan IKM tahu sebanyak 85.360 unit usaha, sedangkan untuk IKM kecap dan tauco 3.600 unit usaha, serta olahan lainnya sebanyak 3.440 unit usaha yang tersebar di hampir seluruh wilayah Indonesia. Berdasarkan data tersebut, permintaan kedelai pada industri tahu dan tempe lebih tinggi jika dibandingkan untuk industri kecap dan tauco, hal ini dikarenakan permintaan kedelai untuk industri kecap dan tauco tidak terlalu tinggi jika dibandingkan dengan permintaan kedelai pada industri tahu dan tempe (Mahabirama et al., 2013).

Salah satu sentra industri olahan kedelai yang ada di Kabupaten Sleman yaitu terletak di kecamatan Seyegan dan kecamatan Gamping. Di daerah tersebut, banyak industri rumah tangga maupun industri kecil yang memanfaatkan komoditas kedelai untuk diolah menjadi produk olahan tahu. Berdasarkan data yang diperoleh dari Dinas Perdagangan, Perindustrian, dan Koperasi Kabupaten Sleman pada tahun 2016, dapat diketahui bahwa jumlah industri olahan kedelai yang ada di kecamatan Seyegan dan kecamatan 
Gamping mencapai 76 unit usaha dengan total nilai produksi sebesar hampir 15 milyar rupiah pada tahun 2015. Data tersebut semakin menegaskan bahwa di dua kecamatan tersebut memang menjadi daerah sentra industri tahu yang ada di Kabupaten Sleman. Banyaknya jumlah industri olahan kedelai ini, menjadikan permintaan kedelai untuk kebutuhan industri juga meningkat dan semakin besar. Oleh karena itu, penelitian ini bertujuan untuk mengetahui faktor-faktor yang mempengaruhi permintaan kedelai pada industri tahu, besarnya nilai tambah yang dihasilkan, serta faktor-faktor yang mempengaruhi keuntungan pengrajin tahu di Kabupaten Sleman.

Beberapa penelitian mengungkapkan bahwa faktor-faktor yang mempengaruhi permintaan yaitu variabel harga dan pendapatan keluarga (Hanafi, F.I., Daris, E., dan Rochaeni, S., 2014), jumlah konsumsi (Fatmawati, Rostin, dan Baso, J.N, 2016), harga kedelai dan pendapatan per kapita (Rahmanta, 2015).

\section{METODE PENELITIAN}

Metode dasar yang digunakan dalam penelitian ini adalah metode analisis deskriptif yang digunakan untuk meneliti status kelompok manusia, objek, suatu set kondisi, suatu sistem pemikiran, ataupun suatu kelas peristiwa pada masa sekarang. Metode ini menggambarkan sebuah peristiwa secara sistematis, faktual dan akurat mengenai fakta, sifat $\&$ hubungan antar fenomena yang diteliti (Nasir, 2011).

Penentuan lokasi penelitian dilakukan dengan metode purposive sampling yang dilakukan di Kabupaten Sleman, Daerah Istimewa Yogyakarta dengan pertimbangan bahwa di Kabupaten Sleman terdapat banyak industri tahu dan juga merupakan salah satu daerah sentra industri pengolahan kedelai di Daerah Istimewa Yogyakarta. Lokasi penelitian dilakukan di kecamatan Gamping dan kecamatan Seyegan, sebagai daerah sentra industri olahan kedelai di Kabupaten Sleman.

Penentuan sampel penelitian dilakukan dengan metode proportional random sampling. Menurut Kasiram (2010), metode proportional random sampling yaitu metode pengambilan sampel dari tiaptiap sub populasi dengan memperhitungkan besar kecilnya sub populasi tersebut. Dalam metode ini, jumlah sampel yang diambil sebanding dengan jumlah anggota populasi dari tiap sub populasi tersebut sesuai dengan proporsinya masing-masing, sehingga dapat diperoleh sampel data yang representatif.

Berdasarkan data IKM tahun 2015, jumlah populasi industri yang ada di kecamatan Seyegan dan kecamatan Gamping adalah sebesar 76 populasi, dengan 61 populasi diantaranya berada di kecamatan Seyegan dan 15 populasi sisanya berada di kecamatan Gamping. Dengan 
jumlah populasi tersebut, berdasarkan tabel perhitungan sampel yang telah dirumuskan oleh Issac dan Michael pada taraf kesalahan $5 \%$, maka jumlah sampel yang dapat diambil adalah sejumlah 65 sampel. Karena populasinya tersebar di dua kecamatan yang berbeda, maka sampel penelitian juga diambil secara proporsional. Pengambilan sampel secara proporsional ini dapat dihitung dengan menggunakan rumus alokasi proporsional yaitu sebagai berikut (Kasiram, 2010):

$$
\mathrm{ni}=\frac{\mathrm{Ni}}{\mathrm{N}} \times \mathrm{n}
$$

Dimana:

ni : jumlah sampel menurut lokasi

$\mathrm{Ni}$ : jumlah populasi menurut lokasi

$\mathrm{N}$ : jumlah total populasi

n : jumlah total sampel

Berdasarkan hasil perhitungan, diperoleh hasil bahwa jumlah sampel yang dibutuhkan dari kecamatan Seyegan adalah 52 sampel dan dari kecamatan Gamping adalah 13 sampel. Selanjutnya, penentuan anggota sampel penelitian ini dilakukan secara acak dengan cara mengundi nama dari setiap kecamatan sehingga diperoleh jumlah sampel yang diinginkan.

Metode analisis data yang digunakan untuk mengetahui faktor-faktor yang mempengaruhi permintaan kedelai pada industri tahu di Kabupaten Sleman adalah analisis regresi linear berganda dengan model persamaan logaritma natural $(\ln )$ yaitu:

$$
\begin{aligned}
& \ln \mathrm{D}=\alpha+\beta_{1} \ln \mathrm{X}_{1}+\beta_{2} \ln \mathrm{X}_{2}+\beta_{3} \ln \mathrm{X}_{3} \\
& +\beta_{4} \ln \mathrm{X}_{4}+\beta_{5} \ln \mathrm{X}_{5}+\beta_{6} \mathrm{D}_{1}+\beta_{7} \mathrm{D}_{2}+\varepsilon
\end{aligned}
$$

Keterangan:

$\mathrm{D}=$ Permintaan kedelai (kg/hari)

$\mathrm{X}_{1}=$ Harga kedelai $(\mathrm{Rp} / \mathrm{kg})$

$\mathrm{X}_{2}=$ Upah tenaga kerja (Rp/HKO)

$\mathrm{X}_{3}=$ Harga tahu $(\mathrm{Rp} / \mathrm{kg})$

$\mathrm{X}_{4}=$ Harga kayu bakar (Rp/ikat)

$\mathrm{X}_{5}=$ Harga koagulan $(\mathrm{Rp} / \mathrm{kg})$

$\mathrm{D}_{1}=$ Dummy Mesin Giling

$(0=$ tidak memiliki; 1 = memiliki $)$

$\mathrm{D}_{2}=$ Dummy Anggota KOPTI

$(0$ = bukan anggota; 1 = anggota

KOPTI)

$\alpha=$ intercept

$\beta_{1}-\beta_{7}=$ koefisien regresi

$\varepsilon \quad=$ varian pengganggu

Metode yang digunakan untuk mengukur nilai tambah pada industri rumah tangga tahu adalah analisis nilai tambah metode Hayami.

Ada 3 indikator rasio nilai tambah (Hubeis cit Ngamel, 2012) :

a. Apabila rasio nilai tambah $<15 \%$, maka tergolong rendah,

b. Apabila rasio nilai tambah $15-40 \%$, maka tergolong sedang, dan

c. Apabila rasio nilai tambah $>40 \%$, maka tergolong tinggi.

Untuk melihat hubungan antara keuntungan dan faktor-faktor yang mempengaruhinya digunakan model 
fungsi keuntungan Cobb-Douglas dan ditransformasi ke dalam model logaritma natural (ln), yaitu:

$\ln \pi^{*}=\alpha+\beta_{1} \ln \mathrm{X}_{1}^{*}+\beta_{2} \ln \mathrm{X}_{2}^{*}+\beta_{3} \ln \mathrm{X}_{3}$

$+\beta_{4} \ln \mathrm{X}_{4}+\beta_{5} \ln \mathrm{X}_{5}^{*}+\beta_{6} \ln \mathrm{X}_{6}^{*}+\beta_{7} \ln \mathrm{X}_{7}^{*}+\varepsilon$

Keterangan:

$\pi^{*}=$ Besarnya keuntungan dinormalkan dengan harga tahu $(\mathrm{Rp})$

$\mathrm{X}_{1}^{*}=\mathrm{Upah}$ tenaga kerja dinormalkan dengan harga tahu (Rp/HKO)

$\mathrm{X}_{2}^{*}=$ Harga kedelai dinormalkan dengan harga tahu $(\mathrm{Rp} / \mathrm{kg})$

$\mathrm{X}_{3}=$ Kapasitas produksi $(\mathrm{kg})$

$\mathrm{X}_{4}=$ Pengalaman usaha (tahun)

$\mathrm{X}_{5}^{*}=$ Harga kayu bakar dinormalkan dengan harga tahu (Rp/ikat)

$\mathrm{X}_{6}^{*}=$ Harga kunyit dinormalkan dengan harga tahu $(\mathrm{Rp} / \mathrm{kg})$

$\mathrm{X}_{7}^{*}=$ Harga koagulan dinormalkan dengan harga tahu $(\mathrm{Rp} / \mathrm{kg})$

$\alpha=$ intercept

$\beta_{1}-\beta_{7}=$ koefisien regresi

$\varepsilon \quad=$ varian pengganggu
HASIL DAN PEMBAHASAN

Struktur Biaya Industri Tahu

Biaya Produksi

Dalam menjalankan suatu usaha tidak terlepas dari penggunaan biaya, begitu pula dalam usaha tahu. Salah satu biaya yang sangat berperan penting dalam menjalankan usaha tahu merupakan biaya produksi. Biaya produksi dapat dikatakan efisien apabila pengeluaran biaya tersebut tidak terjadi suatu pemborosan serta mampu enghasilkan output produk dengan kuantitas dan kualitas yang baik (Hidayat dan Salim, 2013). Biaya produksi dalam industri tempe ini meliputi biaya pembelian bahan baku (kedelai), kayu bakar, solar, koagulan, kunyit, dan juga minyak goreng. Pada tabel 1 berikut ini dijelaskan mengenai biaya produksi dalam usaha pengolahan kedelai menjadi tahu.

Berdasarkan tabel 1, dapat dijelaskan bahwa biaya tertinggi yang dikeluarkan oleh pengrajin tahu adalah biaya untuk pembelian kedelai yaitu Rp 196.799,28 per hari. Hal ini dikarenakan bahan

Tabel 1. Rerata Biaya Produksi Industri Tahu di Kabupaten Sleman

\begin{tabular}{clrr}
\hline No. & \multicolumn{1}{c}{ Uraian } & Jumlah Fisik & \multicolumn{1}{c}{ Jumlah (Rp/hari) } \\
\hline 1. & Kedelai (kg) & 26,71 & $196.799,28$ \\
2. & Kayu Bakar (ikat) & 1,14 & $27.162,78$ \\
3. & Solar (liter) & 0,48 & $2.472,00$ \\
4. & Koagulan (kg) & 0,93 & $3.493,08$ \\
5. & Kunyit (kg) & 0,62 & $2.194,80$ \\
6. & Minyak Goreng (liter) & 0,51 & $4.675,17$ \\
\hline & Jumlah & & $236.797,11$ \\
\hline
\end{tabular}

Sumber: Analisis Data Primer, 2016 
Tabel 2. Rerata Biaya Tenaga Kerja Industri Tahu di Kab. Sleman

\begin{tabular}{clrr}
\hline No. & \multicolumn{1}{c}{ Tenaga Kerja } & Jumlah HKO & Nilai Upah (Rp/hari) \\
\hline 1. & Dalam Keluarga & 2,00 & 0,00 \\
2. & Luar Keluarga & 1,67 & $20.875,00$ \\
\hline & Jumlah & 3,67 & $20.875,00$ \\
\hline
\end{tabular}

Sumber: Analisis Data Primer, 2016

baku kedelai ini merupakan bahan baku pokok yang digunakan dalam industri pengolahan kedelai menjadi tahu. Kedelai yang digunakan adalah jenis kedelai impor dan kedelai lokal dengan harga yang variatif, mulai dari $\mathrm{Rp} 6.900,00 /$ kg hingga mencapai $\mathrm{Rp} 8.300,00 / \mathrm{kg}$ tergantung pada jenis dan kualitas kedelai yang digunakan. Biaya terbesar kedua adalah biaya pembelian kayu bakar sebesar Rp 27.162,78 per hari. Seluruh pengrajin tahu menggunakan kayu bakar untuk proses mengolah kedelai menjadi tahu karena biayanya lebih murah dan mudah didapatkan. Selain untuk pembelian bahan baku kedelai dan kayu bakar, pengrajin juga masih harus mengeluarkan biaya produksi lainnya untuk memproduksi tahu, seperti biaya pembelian solar, biaya koagulan, biaya pembelian kunyit, serta biaya pembelian minyak goreng.

\section{Biaya Tenaga Kerja}

Tenaga kerja yang digunakan oleh para pengrajin meliputi tenaga kerja dalam keluarga dan tenaga kerja luar keluarga. Tabel 2 berikut menjelaskan rerata biaya tenaga kerja dalam industri rumah tangga tahu di daerah penelitian.
Berdasarkan tabel 2, dapat dijelaskan bahwa pengrajin tahu di daerah penelitian lebih banyak menggunakan tenaga kerja dalam keluarga, karena proses pembuatan tahu yang mudah dan juga untuk menekan biaya produksi. Rerata penggunaan tenaga kerja dalam keluarga dalam satu hari sebesar $2 \mathrm{HKO}$, sedangkan tenaga kerja luar keluarga sebesar 1,67 HKO dengan nilai upah yang dikeluarkan rata-rata sebesar Rp 20.875,00 per hari. Penentuan besarnya nilai upah dalam industri tahu ini disesuaikan dengan jenis pekerjaan yang dilakukan oleh pekerja, diantaranya adalah sebagai tenaga penggiling kedelai, tenaga juru masak saripati kedelai, tenaga penyaring sari kedelai, tenaga penggoreng tahu (khusus untuk produk tahu goreng), dan lain-lain. Di daerah penelitian, tenaga kerja luar keluarga ini digunakan oleh pengrajin tahu goreng yang memproduksi tahu dalam skala yang cukup besar sebagai tenaga penggoreng tahu yang sudah jadi, sedangkan pengrajin tahu kuning dan tahu putih hanya menggunakan tenaga kerja dalam keluarga saja.

\section{Biaya Penyusutan Alat}

Perhitungan biaya penyusutan ini dilakukan dengan menggunakan metode 
Tabel 3. Rerata Biaya Penyusutan Alat pada Industri Tahu di Kabupaten Sleman

\begin{tabular}{clrr}
\hline No. & \multicolumn{1}{c}{ Jenis Alat } & Jumlah (Rp/hari) & Jumlah (Rp/tahun) \\
\hline 1. & Panci masak & 849,20 & $254.760,00$ \\
2. & Mesin Giling & 488,02 & $146.407,00$ \\
3. & Saringan Ampas & 236,98 & $71.095,00$ \\
4. & Saringan Cetak & 29,28 & $8.783,00$ \\
5. & Blabak & 120,01 & $36.004,00$ \\
6. & Ember & 18,08 & $5.423,00$ \\
7. & Keranjang bambu & 100,24 & $30.073,00$ \\
8. & Serok & 23,68 & $7.105,00$ \\
\hline & Jumlah & $1.865,50$ & $559.650,00$ \\
\hline
\end{tabular}

Sumber: Analisis Data Primer, 2016

garis lurus, sehingga diperlukan informasi mengenai jenis alat yang digunakan, umur ekonomis alat tersebut, harga beli alat, serta nilai sisa dari alat tersebut saat ini. Peralatan yang digunakan untuk memproduksi tahu ini tergolong masih cukup sederhana dan memiliki umur ekonomis yang cukup panjang. Rerata biaya penyusutan alat dapat dilihat pada tabel 3.

Berdasarkan tabel 3, dapat dijelaskan bahwa rerata penyusutan alat tertinggi adalah penyusutan panci masak yaitu Rp 849,20 per hari atau sekitar Rp 254.760,00 per tahun. Hal ini dikarenakan pembuatan panci masak yang bersifat permanen ini memakan biaya cukup mahal, termasuk guna membeli dan merawat wajan untuk memasak tahu. Selain itu, umur ekonomis dari panci masak juga tidak terlalu lama dikarenakan perawatannya kurang memadai. Penyusutan alat terendah adalah penyusutan ember sebesar Rp 18,08 per hari atau Rp 5.423,00 per tahun. Hal ini dikarenakan harga ember yang cukup murah yaitu sekitar Rp 15.000/biji dengan umur ekonomis yang cukup lama.

\section{Biaya Lain-Lain}

Biaya lain-lain meliputi biaya transportasi, biaya listrik, biaya perbaikan alat, biaya pajak bumi dan bangunan, iuran pasar, dan jasa mesin giling. Tabel 4 berikut adalah rerata biaya lain-lain pada industri tahu di Kabupaten Sleman.

Berdasarkan tabel 4, biaya lain-lain terbesar adalah biaya jasa giling yaitu $\mathrm{Rp}$ 4.943,08 per hari atau sekitar Rp 1.482.923,00 per tahun. Hal ini karena tidak semua pengrajin memiliki mesin diesel untuk menggiling kedelainya, sehingga beberapa pengrajin tahu harus menumpang dan membayar biaya jasa giling kepada pengrajin yang mempunyai mesin giling. Biaya lainlain terkecil adalah biaya pajak bumi dan bangunan untuk tempat produksi tahu, yaitu sebesar Rp 113,60 per hari atau sekitar Rp 34.080,00 per tahun. Hal ini karena tempat produksi tahu yang belum terlalu besar dan masih sederhana. 
Tabel 4. Rerata Biaya Lain-Lain Industri Tahu di Kabupaten Sleman

\begin{tabular}{clrr}
\hline No. & \multicolumn{1}{c}{ Jenis Biaya } & Jumlah (Rp/hari) & \multicolumn{1}{c}{ Jumlah (Rp/tahun) } \\
\hline 1. & Transportasi & $3.221,73$ & $966.518,00$ \\
2. & Listrik & $1.433,00$ & $429.900,00$ \\
3. & Perbaikan Alat & $1.315,38$ & $394.615,00$ \\
4. & Pajak PBB & 113,60 & $34.080,00$ \\
5. & Iuran Pasar & 903,81 & $271.143,00$ \\
6. & Jasa Giling & $4.943,08$ & $1.482 .923,00$ \\
\hline & Jumlah & $11.930,60$ & $3.579 .179,00$ \\
\hline
\end{tabular}

Sumber: Analisis Data Primer, 2016

Tabel 5. Rerata Total Biaya Eksplisit pada Industri Tahu di Kabupaten Sleman

\begin{tabular}{clrr}
\hline No. & \multicolumn{1}{c}{ Uraian } & \multicolumn{1}{c}{ Nilai (Rp/hari) } \\
\hline 1. & Biaya Variabel & & \\
& a. Biaya Produksi & & $236.797,11$ \\
& b. Biaya Tenaga Kerja & $20.875,00$ \\
& Jumlah Biaya Variabel (1) & $257.672,11$ & \\
2. & Biaya Tetap & & \\
a. Biaya Penyusutan Alat & & $1.865,50$ \\
& b. Biaya Lain-Lain & $11.930,60$ \\
& Jumlah Biaya Tetap (2) & & \\
& Total Biaya Eksplisit & $13.796,10$ & \\
3. & & $271.468,21$ \\
\hline
\end{tabular}

Sumber: Analisis Data Primer, 2016

\section{Total Biaya Eksplisit}

Biaya produksi dalam industri rumah tangga tahu dibedakan menjadi dua, yaitu biaya tetap dan biaya variabel. Biaya tetap dalam industri tahu ini meliputi biaya penyusutan alat dan biaya lain-lain. Biaya variabel dalam industri tahu ini meliputi biaya produksi dan biaya tenaga kerja luar keluarga. Rerata total biaya eksplisit pada industri tahu dapat dilihat pada tabel 5 .

Berdasarkan tabel 5, biaya terbesar dalam industri tahu adalah biaya variabel Rp 257.672,11 per hari yang terdiri dari biaya produksi dan biaya tenaga kerja dengan kontribusi terbesar terdapat pada biaya produksi yaitu Rp 236.797,11 per hari. Hal ini dikarenakan kebutuhan biaya produksi untuk produksi tahu cukup besar, salah satunya untuk pembelian kedelai yang merupakan bahan baku utama dan satu-satunya dalam produksi tahu. Biaya tetap terbesar yang dikeluarkan oleh pengrajin adalah biaya lain-lain, yaitu $\mathrm{Rp}$ 11.930,60 per hari. Hal ini dikarenakan adanya biaya jasa giling oleh pengrajin dan juga biaya transportasi untuk membawa produk tahu ke pasar yang jaraknya rata- 
rata cukup jauh, sehingga total biaya eksplisit yang dikeluarkan pengrajin adalah Rp 271.468,21 per hari.

\section{Analisis Pendapatan}

Pendapatan dapat diketahui dengan cara menghitung selisih antara penerimaan dengan total biaya yang dikeluarkan dalam proses produksi. Rerata pendapatan pengrajin tahu dapat dilihat pada tabel 6 .

Berdasarkan tabel 6, penerimaan pengrajin tahu rata-rata $\mathrm{Rp} 345.101,92$ per hari yang diperoleh dari hasil perkalian antara rata-rata produksi tahu per hari dengan harga rata-rata tertimbang produk tahu yang diproduksi oleh pengrajin. Dari penerimaan tersebut, dikurangi dengan biaya variabel dan biaya tetap. Biaya variabel yang dimaksud adalah biaya produksi dan biaya tenaga kerja dengan total biaya Rp 257.672,11 per hari serta biaya tetap yaitu biaya penyusutan alat dan biaya lain-lain dengan total biaya

Tabel 6. Rerata Pendapatan pada Industri Tahu di Kab. Sleman

\begin{tabular}{llr}
\hline No. & Uraian & Nilai (Rp/hari) \\
\hline 1. & Penerimaan & \\
& a. Produksi Fisik (kg) & 50,84 \\
& b. Harga Produk (Rp/kg) & $6.788,00$ \\
& Total Penerimaan (Rp) & $345.101,92$ \\
& (1) & \\
2. & Biaya Eksplisit & \\
& a. Bibit Tetap (Rp) & $13.796,10$ \\
& b. Biaya Variabel (Rp) & $257.672,11$ \\
& Total Biaya Eksplisit & $271.468,21$ \\
& (Rp) (2) & \\
3. & Pendapatan (Rp) (1-2) & $73.633,71$ \\
\hline
\end{tabular}

Sumber: Analisis Data Primer, 2016
Rp 13.796,10 per hari. Dari perhitungan tersebut, diperoleh pendapatan rata-rata pengrajin tahu Rp 73.633,71 per hari.

\section{Analisis Keuntungan}

Rerata keuntungan industri rumah tangga tahu di Kabupaten Sleman dapat dilihat pada tabel 7 berikut.

Tabel 7. Rerata Keuntungan pada Industri Tahu di Kab. Sleman

\begin{tabular}{clr}
\hline No. & \multicolumn{1}{c}{ Uraian } & \multicolumn{1}{c}{$\begin{array}{c}\text { Nilai }(\mathrm{Rp} / \\
\text { hari })\end{array}$} \\
\hline 1. & Pendapatan (1) & $73.633,71$ \\
2. & Biaya Implisit & \\
& a. Biaya TKDK & $25.000,00$ \\
& b. Bunga modal sendiri & 66,94 \\
& Total B. Implisit (2) & $25.066,94$ \\
3. & Keuntungan (1-2) & $48.566,77$ \\
\hline
\end{tabular}

Sumber: Analisis Data Primer, 2016

Berdasarkan tabel 7, rerata keuntungan yang diperoleh pengrajin tahu adalah $\mathrm{Rp}$ 48.566,77 per hari. Keuntungan ini diperoleh dari selisih antara pendapatan pengrajin dengan biaya implisit. Pendapatan yang diperoleh pengrajin yaitu $R p$ 73.633,71 per hari dan biaya implisit yang dikeluarkan adalah Rp 25.066,94 per hari, yang terdiri dari biaya tenaga kerja dalam keluarga $\mathrm{Rp}$ 25.000 per hari dan bunga modal sendiri $\mathrm{Rp}$ 66,94 per hari.

Analisis Faktor-Faktor yang Mempengaruhi Permintaan Kedelai pada Industri Tahu di Kab. Sleman

Permintaan kedelai sebagai salah satu bahan baku yang dibutuhkan oleh 
industri, khususnya industri tahu cenderung dipengaruhi oleh permintaan masyarakat pada produk yang dihasilkan dari industri tahu tersebut. Semakin tinggi permintaan masyarakat terhadap produk yang dihasilkan, akan berdampak pada tingkat permintaan industri terhadap bahan baku.

Dalam penelitian ini, faktor yang diduga mempengaruhi permintaan kedelai pada industri tahu yaitu harga kedelai, upah tenaga kerja, harga tahu, harga kayu bakar, harga koagulan, status kepemilikan mesin giling, dan status keanggotaan KOPTI (Koperasi Tahu Tempe Indonesia). Hasil analisis regresi mengenai faktor yang mempengaruhi permintaan kedelai pada industri tahu dapat dilihat pada tabel 8 berikut.
Berdasarkan tabel 9, nilai Adjusted $R^{2}$ adalah 0,315 yang menunjukkan bahwa sebesar $31,5 \%$ variasi variabel dependen, yaitu permintaan kedelai dapat dijelaskan oleh variabel independen (harga kedelai, upah tenaga kerja, harga tahu, harga kayu bakar, harga koagulan, status kepemilikan mesin giling, dan status keanggotaan KOPTI). Sisanya sebesar $68,5 \%$ dijelaskan oleh variabel lain di luar model.

Hasil analisis diperoleh nilai $\mathrm{F}$ sig. sebesar $0,000(<0,05)$, yang berarti variabel independen (harga kedelai, upah tenaga kerja, harga tahu, harga kayu bakar, harga koagulan, status kepemilikan mesin giling, dan status keanggotaan KOPTI) secara bersama-sama berpengaruh signifikan

Tabel 8. Hasil Analisis Regresi Linear Berganda Faktor-Faktor yang Mempengaruhi Permintaan Kedelai pada Industri Tahu di Kabupaten Sleman

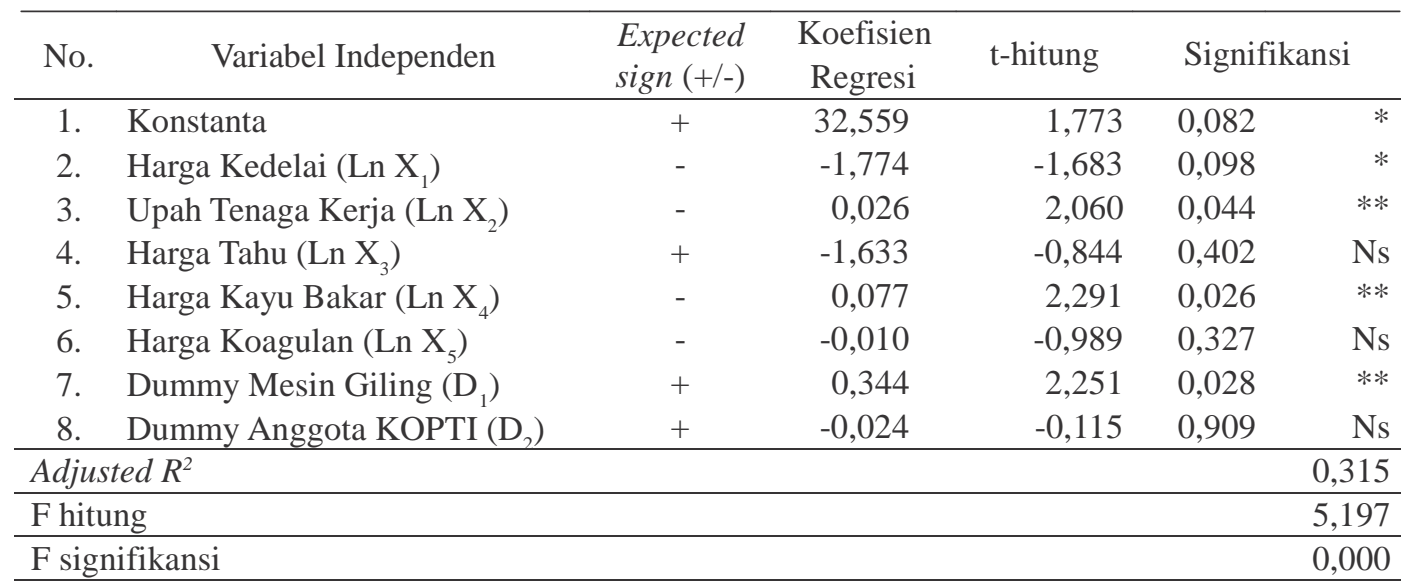

Sumber: Analisis Data Primer, 2016

Keterangan:

** = signifikansi pada tingkat kepercayaan 95\% $(\alpha=0,05)$

* $\quad=$ signifikansi pada tingkat kepercayaan $90 \%(\alpha=0,10)$

ns $\quad=$ tidak signifikan 
terhadap variabel dependennya, yaitu permintaan kedelai pada industri rumah tangga tahu.

Variabel independen yang berpengaruh signifikan adalah harga kedelai pada tingkat kepercayaan $90 \%$, serta upah tenaga kerja, harga kayu bakar, dan dummy mesin giling pada tingkat kepercayaan 95\%. Penjelasan untuk setiap variabel yang berpengaruh signifikan dalam penelitian ini adalah sebagai berikut:

1) Konstanta

Koefisien regresi dari konstanta adalah 32,559 dengan signifikansi 0,082 ( $<\alpha=10 \%)$, sehingga, nilai konstanta berpengaruh signifikan terhadap permintaan kedelai pada industri tahu di Kabupaten Sleman. Dari hasil tersebut, apabila semua variabel independen yang terlibat dalam analisis regresi itu diabaikan, maka permintaan kedelai pada industri tahu sebesar ln 32,559.

\section{2) Harga Kedelai}

Koefisien regresi dari harga kedelai adalah -1,774 dengan signifikansi 0,098 ( $<\alpha=10 \%)$, sehingga, variabel harga kedelai berpengaruh signifikan terhadap permintaan kedelai pada industri tahu di Kabupaten Sleman. Kedelai ini merupakan bahan baku utama yang mutlak diperlukan dalam memproduksi tahu. Tanpa adanya kedelai ini, maka produk tahu juga tidak akan bisa diproduksi. Ketika harga kedelai ini mengalami fluktuasi harga, pengrajin akan tetap membeli kedelai tersebut untuk memenuhi kebutuhan bahan baku pembuatan tahu ini, dengan mengurangi volume pembeliannya untuk dapat menekan biaya produksi.

\section{3) Upah Tenaga Kerja}

Koefisien regresi dari upah tenaga kerja adalah sebesar 0,026 dengan nilai signifikansi 0,044 (< $\alpha=5 \%)$. Sehingga, variabel upah tenaga kerja berpengaruh signifikan terhadap permintaan kedelai pada industri tahu di Kabupaten Sleman. Dalam industri ini, tenaga kerjanya sebagian besar merupakan tenaga kerja dalam keluarga. Namun, untuk pengrajin tahu goreng hampir seluruhnya menambah tenaga kerja luar keluarga dengan jumlah yang variatif. Ketika terjadi kenaikan upah tenaga kerja luar keluarga, pengrajin akan tetap menggunakan tenaga kerja dari luar keluarga tersebut untuk mengefisienkan produksi tahu. Hal ini dilakukan karena tenaga kerja luar keluarga ini sebagian besar sebagai tenaga penggoreng tahu untuk produk tahu goreng, oleh karena itu dengan memanfaatkan tenaga kerja dari luar keluarga ini pengrajin tetap dapat memproduksi tahu dalam jumlah yang maksimal setiap harinya.
4) Harga Kayu Bakar
Koefisien regresi dari harga kayu bakar adalah 0,077 dengan signifikansi $0,026(<\alpha=5 \%)$, sehingga, variabel 
harga kayu bakar berpengaruh signifikan terhadap permintaan kedelai pada industri tahu di Kabupaten Sleman. Kebutuhan kayu bakar bagi pengrajin tahu ini cukup penting, karena kayu bakar ini cukup murah dan mudah didapatkan, sehingga dapat menekan biaya produksi. Dalam memenuhi kebutuhan penggunaan kayu bakar ini sudah disesuaikan dengan jumlah kedelai yang akan di masak dan tingkat kebutuhannya sudah dapat diperkirakan sebelumnya. Walaupun harga kayu bakar mengalami fluktuasi harga, pengrajin tetap menggunakan kayu bakar tersebut dan akan diimbangi juga dengan peningkatan permintaan kedelai untuk industri tahu tersebut.

\section{5) Dummy Mesin Giling}

Koefisien regresi dari dummy kepemilikan mesin giling kedelai adalah 0,344 dengan signifikansi $0,028(<\alpha=5 \%)$. Status kepemilikan mesin giling pada industri tahu ini terdapat perbedaan yang berpengaruh pada tingkat permintaan kedelai pada industri tahu. Hal ini dikarenakan pengrajin yang memiliki mesin giling cenderung akan lebih leluasa dalam menggiling kedelai yang akan di masak tanpa harus mengeluarkan biaya apapun di luar biaya bahan bakar mesin tersebut. Pengrajin yang tidak memiliki mesin giling tidak bisa leluasa dalam menggiling kedelai, karena pengrajin tersebut harus datang ke pengrajin lain yang memiliki mesin giling dengan membayar biaya jasa giling yang sudah disepakati sebelumnya, yaitu rata-rata Rp 5.000,00/hari. Dengan biaya produksi yang sama, pengrajin yang memiliki mesin giling akan cenderung lebih banyak dalam menggiling kedelai untuk pembuatan tahu dibandingkan dengan pengrajin yang tidak memiliki mesin giling tersebut.

\section{Analisis Nilai Tambah}

Berdasarkan tabel 9, untuk menghasilkan produk tahu kuning sebanyak 48,702 kg/hari dibutuhkan bahan baku kedelai sebanyak $23,269 \mathrm{~kg} /$ hari. Nilai faktor konversi 2,093 menunjukkan bahwa setiap 1 kg bahan baku kedelai dapat menghasilkan 2,093 kg produk tahu kuning. Nilai tambah yang dihasilkan tahu kuning adalah $\mathrm{Rp}$ 3.999,6/kg kedelai dengan rasio nilai tambah $28,15 \%$ dari nilai produk tahu. Keuntungan yang diperoleh dari industri tahu kuning ini yaitu Rp 2.935,4/kg kedelai dengan tingkat keuntungan 73,39\% dari nilai tambah. Margin pengolahan kedelai menjadi produk tahu kuning yaitu Rp 6.852,3/kg dengan bagian pendapatan tenaga kerja $15,53 \%$, nilai input lain 41,63\%, dan keuntungan pemilik modal $42,84 \%$.

Untuk menghasilkan produk tahu putih $70,4 \mathrm{~kg} /$ hari dibutuhkan bahan baku kedelai sebanyak 34,2 kg/hari. Nilai faktor konversi 2,058 menunjukkan bahwa setiap $1 \mathrm{~kg}$ bahan baku kedelai dapat menghasilkan 2,058 kg produk 
Tabel 9. Nilai Tambah Pengolahan Kedelai Menjadi Berbagai Jenis Produk Tahu

\begin{tabular}{clrrr}
\hline No. & \multicolumn{1}{c}{ Variabel } & \multicolumn{1}{c}{ Jenis Tahu } & \\
\hline I. & Output, Input, Harga & Tahu Kuning & \multicolumn{1}{c}{ Tahu Putih } & Tahu Goreng \\
\hline 1. & Hasil produksi (kg/hari) & 48,702 & 70,4 & 48,6 \\
2. Bahan baku (kg/hari) & 23,269 & 34,2 & 35,5 \\
3. Tenaga kerja (HKO) & 1,981 & 2 & 1,87 \\
4. Faktor konversi & 2,093 & 2,0585 & 1,369 \\
5. Koefisien tenaga kerja (HKO/kg) & 0,0851 & 0,0585 & 0,0527 \\
6. Harga produk (Rp/kg) & 6.788 & 8.400 & 16.200 \\
7. & Upah tenaga kerja (Rp/HKO) & 12.500 & 12.500 & 12.500 \\
\hline II. Penerimaan dan Keuntungan & & & \\
\hline 8. Harga bahan baku (Rp/kg) & 7.355 & 7.800 & 7.300 \\
9. Sumbangan input lain (Rp/kg) & $2.852,7$ & 4.316 & $9.275,7$ \\
10. Nilai produk (Rp/kg) & 14.207 & 17.291 & 22.178 \\
11. a. Nilai tambah (Rp/kg) & $\mathbf{3 . 9 9 9 , 6}$ & $\mathbf{5 . 1 7 5 , 2}$ & $\mathbf{5 . 6 0 2 , 4}$ \\
& b. Rasio nilai tambah (\%) & $\mathbf{2 8 , 1 5 2}$ & $\mathbf{2 9 , 9 3}$ & $\mathbf{2 5 , 2 6 1}$ \\
12. a. Imbalan tenaga kerja (Rp/kg) & $1.064,2$ & 730,99 & 658,45 \\
& b. Pangsa tenaga kerja (\%) & 26,607 & 14,125 & 11,753 \\
13. a. Keuntungan usaha (Rp/kg) & $2.935,4$ & $4.444,2$ & $4.943,9$ \\
& b. Tingkat keuntungan usaha (\%) & 73,393 & 85,875 & 88,247 \\
\hline III. Imbalan Faktor Produksi & & & \\
\hline 14. Margin pengolahan (Rp/kg) & $6.852,3$ & $9.491,2$ & 14.878 \\
& a. Pendapatan tenaga kerja (\%) & 15,53 & 7,7018 & 4,4257 \\
& b. Sumbangan input lain (\%) & 41,631 & 45,474 & 62,345 \\
& c. Keuntungan usaha (\%) & 42,839 & 46,825 & 33,23 \\
\hline
\end{tabular}

Sumber: Analisis Data Primer, 2016

tahu putih. Nilai tambah yang dihasilkan dari tahu putih ini adalah Rp 5.175,2/kg kedelai dengan rasio nilai tambah 29,93\% dari nilai produk tahu. Keuntungan dari industri tahu putih ini Rp 4.444,2/ kg kedelai dengan tingkat keuntungan $85,87 \%$ dari nilai tambah. Margin pengolahan kedelai menjadi produk tahu putih adalah Rp 9.491,2/kg dengan bagian pendapatan tenaga kerja $7,70 \%$, nilai input lain $45,47 \%$, dan keuntungan pemilik modal $46,82 \%$.

Untuk menghasilkan produk tahu goreng sebanyak 48,6 kg/hari dibutuhkan bahan baku kedelai sebanyak 35,5 kg/hari.
Nilai faktor konversi 1,369 menunjukkan bahwa setiap $1 \mathrm{~kg}$ bahan baku kedelai dapat menghasilkan 1,369 $\mathrm{kg}$ produk tahu goreng. Nilai tambah yang dihasilkan dari tahu goreng ini Rp 5.602,4/kg kedelai dengan rasio nilai tambah $25,26 \%$ dari nilai produk tahu. Keuntungan dari industri tahu goreng ini yaitu Rp 4.943,9/kg kedelai dengan tingkat keuntungan $88,25 \%$ dari nilai tambah tersebut. Margin pengolahan kedelai menjadi produk tahu goreng ini adalah $\mathrm{Rp}$ 14.878/kg dengan bagian pendapatan tenaga kerja $4,43 \%$, nilai input lain $62,34 \%$, dan keuntungan pemilik modal $33,23 \%$. 
Tabel 10.Hasil Analisis Regresi Linear Berganda Faktor-Faktor yang Mempengaruhi Keuntungan Industri Tahu di Kabupaten Sleman

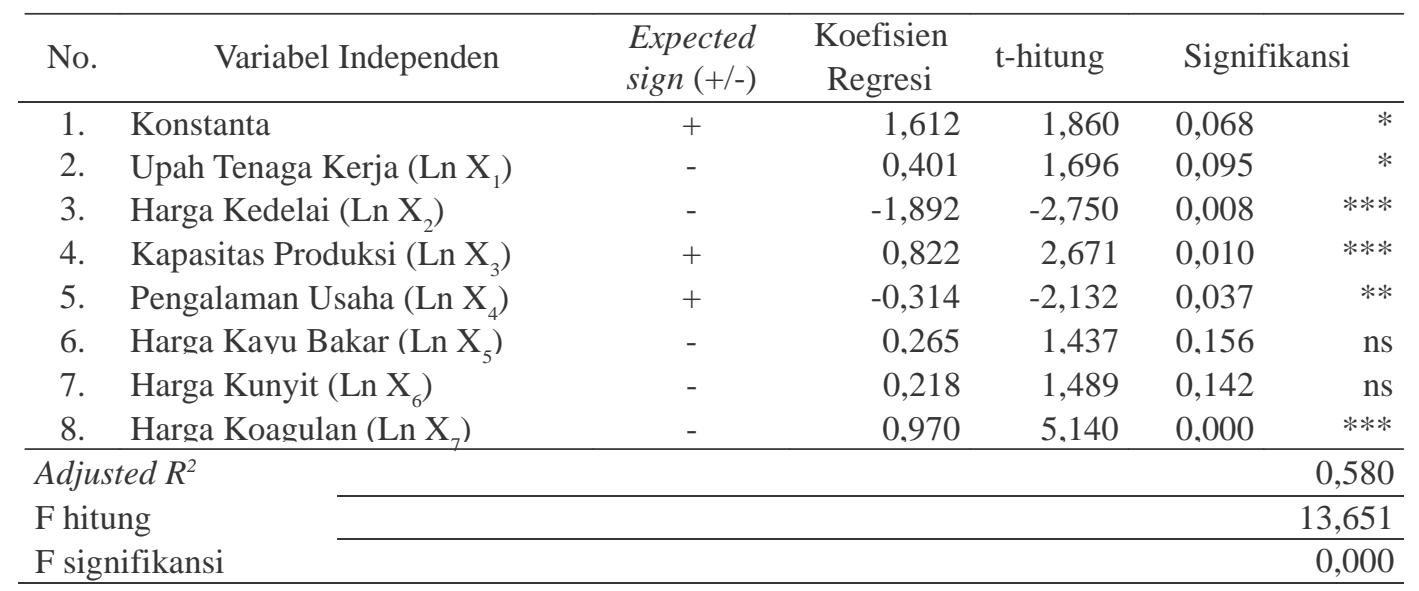

Sumber: Analisis Data Primer, 2016

Keterangan:

$$
\begin{array}{ll}
* * * & =\text { signifikansi pada tingkat kepercayaan } 99 \%(\alpha=0,01) \\
* * & =\text { signifikansi pada tingkat kepercayaan } 95 \%(\alpha=0,05) \\
* & =\text { signifikansi pada tingkat kepercayaan } 90 \%(\alpha=0,10) \\
\mathrm{ns} & =\text { tidak signifikan }
\end{array}
$$

\section{Analisis Faktor yang Mempengaruhi}

\section{Keuntungan Industri Tahu}

Dalam penelitian ini, faktor yang diduga mempengaruhi keuntungan industri tahu antara lain upah tenaga kerja, harga kedelai, kapasitas produksi, pengalaman usaha, harga kayu bakar, harga kunyit, dan harga koagulan.

Berdasarkan tabel 10, nilai Adjusted $R^{2}$ adalah 0,580 , yang berarti sebesar $58 \%$ variasi variabel dependen, yaitu keuntungan industri tahu dapat dijelaskan oleh variabel independen yang terdiri dari upah tenaga kerja, harga kedelai, kapasitas produksi, pengalaman usaha, harga kayu bakar, harga kunyit, dan harga koagulan, sedangkan $42 \%$ sisanya dijelaskan oleh variabel lain di luar model regresi.
Hasil analisis diperoleh nilai $\mathrm{F}$ sig. sebesar 0,000 $(<0,05)$, yang berarti bahwa variabel independen, yaitu upah tenaga kerja, harga kedelai, kapasitas produksi, pengalaman usaha, harga kayu bakar, harga kunyit, dan harga koagulan secara bersama berpengaruh signifikan terhadap variabel dependennya, yaitu keuntungan industri tahu per harinya.

Variabel independen yang berpengaruh signifikan secara individu adalah upah tenaga kerja pada tingkat kepercayaan $90 \%$, pengalaman usaha pada tingkat kepercayaan 95\%, serta harga kedelai, kapasitas produksi, dan harga koagulan pada tingkat kepercayaan $99 \%$. Berikut ini adalah penjelasan untuk setiap variabel independen yang berpengaruh 
signifikan dalam penelitian ini:

1) Konstanta

Koefisien regresi dari konstanta adalah 1,612 dengan signifikansi $0,068(<\alpha=10 \%)$, sehingga, nilai konstanta ini berpengaruh signifikan terhadap keuntungan industri tahu di Kabupaten Sleman. Dari hasil tersebut, apabila semua variabel independen, yaitu upah tenaga kerja, harga kedelai, kapasitas produksi, pengalaman usaha, harga kayu bakar, harga kunyit, dan harga koagulan diabaikan, maka besarnya keuntungan industri tahu adalah $\ln 1,612$.

\section{2) Upah Tenaga Kerja}

Koefisien regresi dari upah tenaga kerja adalah 0,401 dengan signifikansi $0,095(<\alpha=10 \%)$. Variabel upah tenaga kerja berpengaruh signifikan terhadap keuntungan industri tahu di Kabupaten Sleman. Nilai koefisien regresi tersebut menunjukkan bahwa peningkatan upah tenaga kerja 1 persen akan menyebabkan peningkatan keuntungan industri tahu di Kabupaten Sleman 0,401 persen. Hal ini karena adanya kenaikan upah bagi para tenaga kerja luar keluarga, diharapkan produktivitas kerja dari tenaga kerja tersebut dapat meningkatkan hasil produksi tahu dan dapat berdampak pada tingkat keuntungan usaha yang diperoleh pengrajin. Di daerah penelitian, upah tenaga kerja ini dikeluarkan oleh pengrajin yang menggunakan tenaga kerja luar keluarga. Bagi pengrajin yang hanya menggunakan tenaga kerja dalam keluarga, adanya kenaikan upah ini tidak terlalu berpengaruh bagi pengrajin. Hal ini dikarenakan pengrajin tidak perlu mengeluarkan upah tenaga kerja. Kondisi ini tetap berdampak positif pada keuntungan industri tahu tersebut, karena peningkatan produktivitas kerja tetap dapat diupayakan maksimal dan lebih mudah dilakukan.

\section{3) Harga Kedelai}

Koefisien regresi dari harga kedelai adalah -1,892 dengan signifikansi 0,008 $(<\alpha=1 \%)$, sehingga, variabel harga kedelai berpengaruh signifikan terhadap keuntungan industri tahu di Kabupaten Sleman. Nilai koefisien regresi tersebut menunjukkan bahwa peningkatan harga kedelai 1 persen dapat menyebabkan penurunan tingkat keuntungan dari industri tahu di Kabupaten Sleman 1,892 persen. Hal ini dikarenakan dengan adanya kenaikan harga kedelai ini, para pengrajin harus menambah modal produksi untuk dapat memperoleh kedelai tersebut. Selain itu, beberapa pengrajin juga menyiasati kenaikan harga kedelai ini dengan mengurangi penggunaan kedelai. Hal ini dimaksudkan agar biaya produksi yang dikeluarkan oleh para pengrajin tidak terlalu membengkak. Dampaknya, produksi tahu yang dihasilkan pun mengalami penurunan, sehingga tingkat keuntungan yang diterima oleh pengrajin juga berkurang. 
4) Kapasitas Produksi

Koefisien regresi dari kapasitas produksi adalah 0,822 dengan signifikansi $0,010(<\alpha=1 \%)$. Variabel kapasitas produksi berpengaruh signifikan terhadap keuntungan industri tahu di Kabupaten Sleman. Nilai koefisien regresi tersebut menunjukkan bahwa peningkatan kapasitas produksi 1 persen dapat menyebabkan peningkatan keuntungan industri tahu di Kabupaten Sleman 0,822 persen. Hal ini karena dengan terjadinya peningkatan kapasitas produksi ini, jumlah bahan baku kedelai yang dimasak pun juga akan mengalami peningkatan. Peningkatan kapasitas produksi ini berbanding lurus dengan jumlah produk tahu yang dihasilkan oleh pengrajin. Peningkatan kapasitas produksi ini akan menyebabkan peningkatan penerimaan yang diterima oleh pengrajin dan diikuti dengan peningkatan keuntungan yang diperoleh.

\section{5) Pengalaman Usaha}

Koefisien regresi pengalaman usaha adalah $-0,314$ dengan signifikansi $0,037(<\alpha=5 \%)$, sehingga, variabel pengalaman usaha berpengaruh signifikan terhadap keuntungan industri tahu di Kabupaten Sleman. Nilai koefisien regresi tersebut menunjukkan bahwa peningkatan pengalaman usaha 1 persen dapat menyebabkan penurunan tingkat keuntungan industri tahu di Kabupaten Sleman 0,314 persen. Terjadinya penurunan keuntungan ini berkaitan erat dengan usia pengrajin tahu. Di daerah penelitian, pengrajin yang mempunyai pengalaman usaha sudah cukup lama cenderung akan mengurangi jumlah produksi tahu karena usianya yang sudah tidak produktif lagi untuk memproduksi tahu dalam jumlah yang banyak. Dengan berkurangnya volume produksi tahu oleh pengrajin yang sudah lebih berpengalaman ini, juga akan mengurangi keuntungan yang diperoleh pengrajin tahu tersebut.

\section{6) Harga Koagulan}

Koefisien regresi dari harga koagulan adalah 0,970 dengan signifikansi $0,000(<\alpha=1 \%)$. Variabel harga koagulan berpengaruh signifikan terhadap keuntungan industri tahu di Kabupaten Sleman. Nilai koefisien regresi ini menunjukkan bahwa peningkatan harga koagulan 1 persen akan menyebabkan peningkatan keuntungan industri tahu di Kabupaten Sleman 0,970 persen. Hal ini karena koagulan ini termasuk bahan penolong yang penting peranannya untuk memproduksi tahu yang berkualitas baik. Ketika terjadi fluktuasi harga koagulan, pengrajin akan tetap menggunakan koagulan ini sebagai bahan penggumpal sari kedelai menjadi tahu. Selain itu, beberapa pengrajin juga menyiasatinya dengan mengurangi volume penggunaan koagulan chioko serta mensubstitusinya dengan air biang tahu dari proses 
produksi sebelumnya. Dengan begitu, biaya produksi yang dikeluarkan pengrajin pun dapat ditekan. Terjadinya fluktuasi harga koagulan ini sudah dapat diantisipasi sebelumnya dan tetap dapat meningkatkan keuntungan industri tahu yang diperoleh pengrajin.

\section{KESIMPULAN DAN SARAN Kesimpulan}

1. Harga kedelai berpengaruh negatif terhadap permintaan kedelai pada industri tahu di Kabupaten Sleman, sedangkan upah tenaga kerja dan harga kayu bakar berpengaruh positif terhadap permintaan kedelai pada industri tahu di Kabupaten Sleman. Permintaan kedelai oleh pengrajin yang memiliki mesin giling juga lebih banyak dibandingkan pengrajin yang tidak memiliki mesin giling.

2. Nilai tambah dari produk tahu goreng sebesar Rp 5.602,4/kg kedelai, tahu putih sebesar Rp 5.175,2/kg kedelai, dan tahu kuning sebesar Rp 3.999,6/ kg kedelai.

3. Upah tenaga kerja, kapasitas produksi, dan harga koagulan berpengaruh positif terhadap tingkat keuntungan industri tahu di Kabupaten Sleman, sedangkan harga kedelai \& pengalaman usaha berpengaruh negatif terhadap tingkat keuntungan industri tahu di Kabupaten Sleman.

\section{Saran}

1. Sebagai upaya untuk menstabilkan harga dan ketersediaan bahan baku kedelai, perlu pengaktifan kembali serta optimalisasi fungsi koperasi pengrajin tahu dan tempe (KOPTI) di daerah penelitian sebagai distributor bahan baku kedelai, sehingga biaya produksi dapat ditekan dan keuntungan yang diperoleh pengrajin dapat ditingkatkan.

2. Sebaiknya pengrajin tahu berusaha untuk mengembangkan industri ini dengan cara mengolah kedelai tersebut menjadi produk-produk lainnya selain produk tahu, sehingga nilai tambah dari kedelai dapat ditingkatkan.

\section{DAFTAR PUSTAKA}

Damardjati, D. S., Marwoto, D.K.S. Swastika, D.M.Arsyad, Y. Hilman. 2005. Prospek dan Arah Pengembangan Agribisnis Kedelai. Jakarta: Badan Litbang Pertanian, Departemen Pertanian.

Fatmawati, Rostin, dan Baso, J.N., 2016, Faktor-Faktor yang Mempengaruhi Permintaan Daging Sapi di Indonesia, Jurnal Ekonomi 1 (1) : 128-134.

Hanafi, F.I., Daris, E., dan Rochaeni, S., 2014, Analisis Faktor-Faktor yang Mempengaruhi Permintaan Tempe di Kelurahan Jurangmangu Timur, Pondok Aren, Tangerang Selatan. Jurnal Agribisnis 8 (1): 45-58. 
Hidayat, L. dan Salim, S., 2013, Analisis Biaya Produksi dalam Meningkatkan Profitabilitas Perusahaan. Jurnal Ilmiah Manajemen Kesatuan 1 (2) : 159-168

Mahabirama, A.K., Kuswanti, H., Daryanto, S., dan Winandi, R. 2013. Analisis Efisiensi dan Pendapatan Usahatani Kedelai di Kabupaten Garut Provinsi Jawa Barat. Jurnal Apl. Manajemen 11 : 197-206.

McFarlane, I. and O'Connor, E.A. 2014. World Soybean Trade: Growth and Sustainability. Modern Economy 5: 580-588.

Ngamel, A.K. 2012. Analisis finansial usaha budidaya rumput laut dan nilai tambah tepung karaginan di Kecamatan Kei Kecil, Kabupaten Maluku Tenggara. Jurnal Sains Terapan Edisi II Vol. 2: 68 - 83.

Rahmanta, 2015, Faktor-Faktor yang Mempengaruhi Permintaan Kedelai di Provinsi Sumatera Utara. Jurnal QE 4 (1): 1-12.

Tanoyo, S. Brilliantoro. 2014. Analisis dampak kenaikan harga kedelai terhadap pendapatan usaha pengrajin tempe skala kecil dan rumah tangga (kasus Kelurahan Krobokan, Kecamatan Semarang Barat, Kota Semarang) [skripsi]. Semarang : Fakultas Ekonomika dan Bisnis. Universitas Diponegoro. 